\title{
Winter Precipitations of Northern Part of Farming-Pastoral Zone and Hulunbuir Grassland
}

\author{
You Xia \\ School of Civil Engineering, Sun Yat-Sen University, Zhuhai, China \\ Email: sunlight805@outlook.com
}

How to cite this paper: Xia, Y. (2021) Winter Precipitations of Northern Part of Farming-Pastoral Zone and Hulunbuir Grassland. Atmospheric and Climate Sciences, 11, 709728.

https://doi.org/10.4236/acs.2021.114042

Received: September 3, 2021

Accepted: October 18, 2021

Published: October 21, 2021

Copyright $\odot 2021$ by author(s) and Scientific Research Publishing Inc. This work is licensed under the Creative Commons Attribution International License (CC BY 4.0).

http://creativecommons.org/licenses/by/4.0/

\section{(c) (i) Open Access}

\begin{abstract}
In January 2018, a high record of monthly total precipitation in northern China drew our attention. The precipitation amount is 4 times more than that in normal winters over the past 30 years. Up to now, many researches over the world focus on the intensity of precipitations or the number of intense precipitations, however, no sufficient study is investigated in the continuous moderate precipitations. The abnormal precipitation in January 2018 in northern China is a typical case of the continuous moderate precipitation. The research region is composed by the northern part of the farming-pastoral zone and the Hulunbuir Grassland. The main method in this study consists of analyzing the abnormal precipitation month by identifying the precipitation types and locations, and exploring the atmospheric circulations at the moment of typical precipitations. The research found that the continuity is the key point for high precipitation amount in January 2018 in Northern China. Besides, this continuity is caused by frequent appearance of cyclones in the vicinity.
\end{abstract}

\section{Keywords}

Continuous Moderate Precipitation, Northern China, Atmospheric

Circulation

\section{Introduction}

Northern China is always considered as a dry region comparing to the southern China. Especially in winter, a dry lasting cold weather dominates in the north. However, the northern China turned to be rich in precipitation in January 2018. The research region, called Region hereafter, is defined by the rectangle limitation comprising northern part of the farming-pastoral ecotone and Hulunbuir Grass- 
land, because both of the mentioned areas are economically relied on winter precipitations for crops growth, pasturage and tourism business. Up to date, many research are focused on the environment changes of such grassland ecosystem due to natural impact factors such as climate change, precipitation, grazing, fire and drought [1] [2] [3] [4] [5]. The present research focuses on precipitation factor on the forest-grassland transition zone. Over the past 30 years from 1988 to 2018, the maximum winter precipitation amount of the Region is no more than $100 \mathrm{~mm}$, meanwhile in January 2018 that exceeds $400 \mathrm{~mm}$. This abnormal phenomenon attracts attention. For winter heavy precipitations, several studies are investigated worldwide. Single winter heavy precipitation occurred in central Japan in January 2016. It is found that the occluding cyclones are the main cause of the heavy precipitations [6]. Cold air out breaks, passing by of extratropical cyclones are also causes of winter heavy precipitations in Japan [7]. In addition, typical winter monsoon pressure patterns also contribute to the inland heavy precipitations in Japan [8]. Along the coast of the Sea of Japan, local-scale depressions and local convergences caused by land breezes are factors for heavy winter precipitations [9]. Studies on heavy winter precipitations in Japan caused by extratropical cyclones further provide information on root causes. The result is that the combination of the warm conveyor belt, the cold conveyor belt and the dry air intrusion is vital in the contribution of the heavy precipitations [10]. Moving to areas above the southeast Canada and the northeast United States, North Atlantic Oscillation is the major cause of the heavy winter precipitation. The positive North Atlantic Oscillation induces less precipitations, while the negative North Atlantic Oscillation causes twice as many heavy precipitation events as the former [11]. In eastern Canada, studies show that the winter precipitations are poorly correlated with the North Atlantic Oscillation [12] [13] [14]. In aspect of sea surface temperature influences, existing studies show that the mesoscale of that can give a remote influence on atmospheric river landfalling, leading to heavy precipitations along the west coast of North America [15]. In addition, heavy winter precipitations in the west mountainous topography of America is also caused by the moisture originating from the Pacific, and transporting upwards through the mountains [16]. For a heavy precipitation event in January 2008 in Iran, a deep low trough above the north of the Caspian Sea caused by a blocking system drives the thermal and moisture gradients [17]. For summer heavy precipitations in Utah, both direct and indirect synoptic factors are important. Moreover, the humidity shift above the Atlantic Ocean plays a crucial role [18]. In Romania, positive North Atlantic Oscillation and blocking phenomenon over the Atlantic-European sector can cause winter precipitations to decrease [19]. Global warming is another key contributor to extratropical cyclones, leading to the increase of the precipitation intensity [20]. Despite studies on heavy winter precipitations are done at a global scale, no studies have focused on inland winter precipitations in the areas in northern China where the cold days can even expand up to half of a year. Moreover, all existing studies relative to precipitations focus on either the intensity of precipitations or the number of 
intense precipitations, which are obvious and easy to draw out attention. Rare research is investigated in finding the hint causes of continuous moderate precipitations. Thus, we target our research at exploring precipitation phenomena in January 2018 in the Region, a typical case of continuous moderate precipitation, and using dynamical analyses to find out the causes of such precipitations. First, we explore the trend of the Region-averaged monthly total precipitations over the recent 30 years without that of January 2018. Second, we study the location of the monthly total precipitations of Januaries in the recent 7 winters. Third, the hourly precipitations within the month are explored. The precipitation rate that exceeds $2 \mathrm{~mm} / \mathrm{h}$ is defined as "heavy precipitation events" for the Region. Lastly, we focus on typical individual heavy precipitation event in January 2018, and use dynamical analyses to investigate in the atmospheric circulations during those precipitations.

\section{Data and Methodology}

\subsection{Definition of the Research Region}

The Region comprises the north part of the farming-pastoral ecotone of China and Hulunbuir Grassland. It is a rectangle area limited by the union of the longitudes and latitudes of the ecotone and the grassland. This rectangle area helps us to understand better conditions of the precipitations and atmospheric circulations, than limiting our sights only on the banding field of ecotone and the square of grassland. The Northern part of Chinese farming-pastoral zone covers $36^{\circ} 30^{\prime} \mathrm{N}-46^{\circ} 42^{\prime} \mathrm{N}$ and $106^{\circ} 16^{\prime} \mathrm{E}-124^{\circ} 51^{\prime} \mathrm{E}$ [21]. The boundary of the Hulunbuir Grassland is limited by towns of Xinbaerhuyouqi, Xinbaerhuzuoqi, Chenbaerhuqi, Ewenkeqi, Hailarqu, Manzhouli, Yakeshishi, Eergunashi. Those towns encircle an area with latitude $48^{\circ} \mathrm{N}-51^{\circ} \mathrm{N}$ and longitude $116.5^{\circ} \mathrm{E}-121^{\circ} \mathrm{E}$. Hence, the Region is defined by $36^{\circ} \mathrm{N}-51^{\circ} \mathrm{N}$ and $106^{\circ} \mathrm{E}-125^{\circ} \mathrm{E}$.

\subsection{Data Source and Methods}

All data used in this research are publicly available. The data of Monthly Total precipitations (SURF_CLI_CHN_PRE_MON_GRID_0.5) have $0.5^{\circ} * 0.5^{\circ}$ horizontal resolution, and they are taken from National Atmospheric Science Data Center of China.

From European Centre for Medium Range Weather Forecasts (ECMWF), ERA5 data is used with temporal resolution of 6 hours, and the horizontal resolution is $1^{\circ} \star 1^{\circ}$ for hourly precipitation, $0.1^{\circ} \star 0.1^{\circ}$ for geopotential, $\mathrm{U}$ and $\mathrm{V}$ components of wind and specific humidity at $200 \mathrm{hPa}, 500 \mathrm{hPa} 700 \mathrm{hPa}$ and 850 $\mathrm{hPa}$.

The hourly precipitation rate is taken as the maximum precipitation amount gleaned in the Region from January 1st 0:00 to 31th 18:00 with time resolution of 6 hours. Then "heavy" precipitation hourly rate is defined by $2 \mathrm{~mm} / \mathrm{h}$ because this value can separate clearly continuous precipitation fold line into individual precipitation events, to give more convenience to our analyses. The dynamical 
analyses include relative humidity, wind field, geopotential height to explore atmospheric circulation above the Region during each heavy precipitation event.

\section{Precipitation Phenomena}

\subsection{Precipitation Trends}

The Region locates in the north part of China, and it is renowned for cold lasting winter days and small amount of precipitations. In our research we only consider the months with the lowest temperature of a year, that is we take December, January and February as winter months. For the recent 30 winters from December 1988 to February 2018, the Regional maximum monthly total precipitation is drawn in Figure 1. The maximum precipitation values oscillate between $0 \mathrm{~mm}$ and $100 \mathrm{~mm}$ with a stable behavior, except the instance of January 2018 which exceeds $400 \mathrm{~mm}$. For the Region-average precipitation, the value of January 2018 is about three times higher than that of normal months.

To see where the value of the maximum precipitation in January 2018 situates through the 30 winters, we draw in Figure 2 Region-averaged and maximum monthly total precipitation using GEV distribution. The Region-averaged monthly total precipitation in dark blue line is centered at $4 \mathrm{~mm}$, and the probability falls to 0 at $15 \mathrm{~mm}$. For the maximum monthly total precipitation in cyan color, the maximum probability locates at $25 \mathrm{~mm}$, and it equals to 0 for precipitation value larger than $150 \mathrm{~mm}$. This means the precipitation value of January 2018 is unprecedented in history.

To understand precipitation trend of the Region, the Region-averaged monthly total precipitation for the 30 winters is drawn in Figure 3. Only in December 1990 the Region-averaged precipitation value is more than $10 \mathrm{~mm}$, while

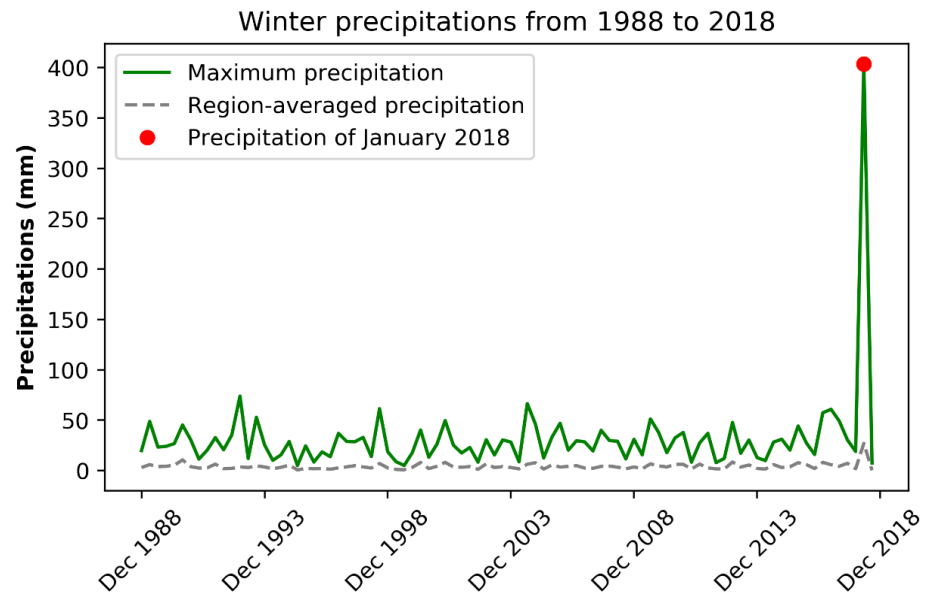

Figure 1. Regional maximum values of monthly total precipitations for recent 30 winters from December 1988 to February 2018 for the months: December, January and February. The horizontal axis is time line and the vertical axis is precipitation amount with units of $\mathrm{mm}$. The green solid line is Regional maximum monthly total precipitation value, and the gray dashed line is the Region-averaged monthly total precipitation. The red spot is the Regional maximum monthly total precipitation value of January 2018. 

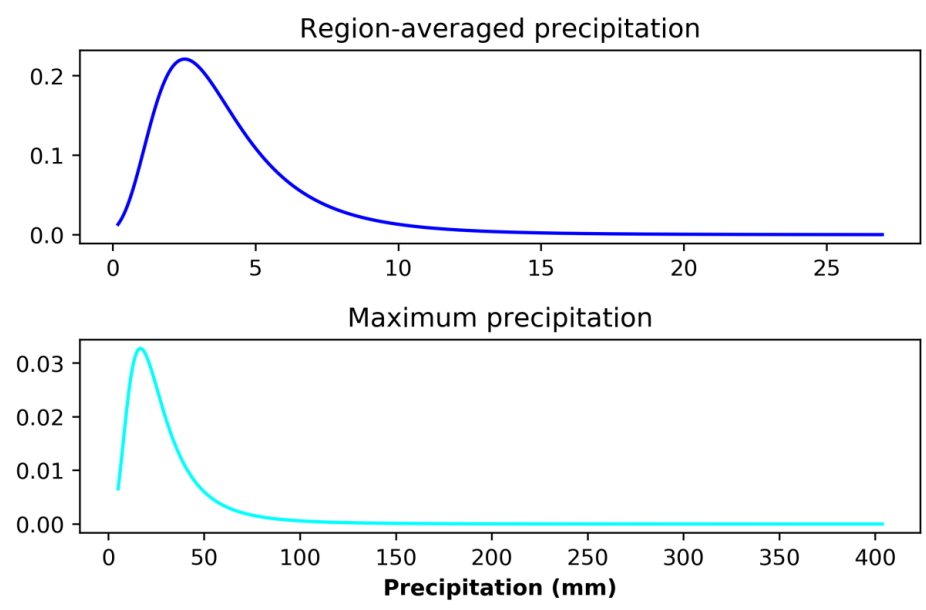

Figure 2. GEV distribution of Region-averaged precipitation and maximum precipitation. The values are taken as monthly total precipitation for winters from 1988 to 2018 . The horizontal axes are precipitation amount in $\mathrm{mm}$, and the vertical axes are probability.

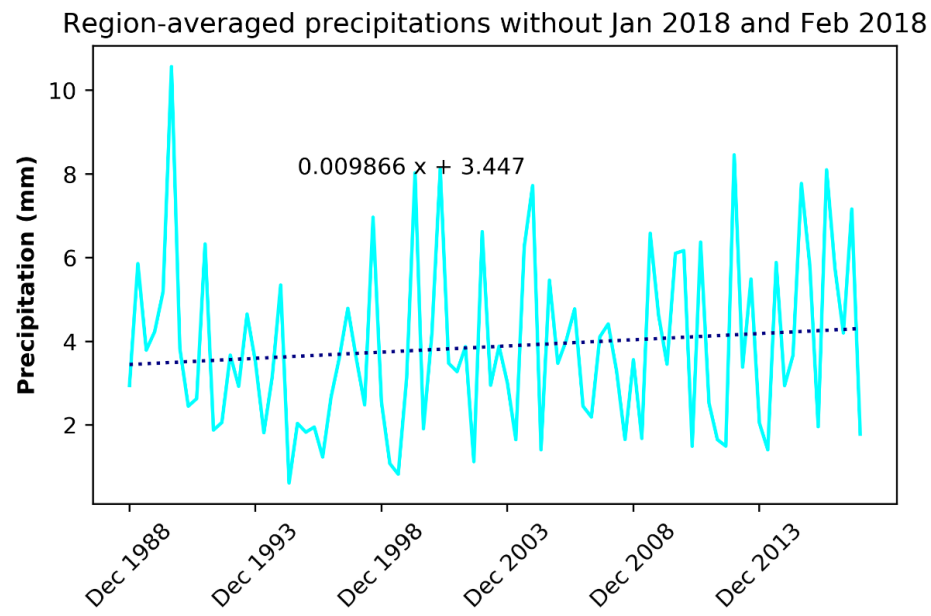

Figure 3. Region-averaged monthly total precipitation without January 2018 and February 2018. The horizontal axis is time line and the vertical axis is precipitation amount in $\mathrm{mm}$. The cyan curve is the Region-averaged monthly total precipitation, and the blue dashed line is the precipitation trend line in first order polynomial fit. The trend line equation is just above the cyan curves in Figure 3.

for other months, this value never exceeds $8 \mathrm{~mm}$. The slope of the trend line is positive, which means the precipitation amount is increasing in the Region. The small value of the slope expresses the tiny amount of growth. The precipitations of the Region are estimated as in a stable state.

\subsection{Precipitation Locations}

For the recent 30 years, the locations of the maximum monthly total precipitation of the Region are mainly separated to five sites. These precipitations are named after those sites: East border precipitation, Northeast precipitation, Southwest precipitation, Coastal precipitation and Inland precipitation.

The precipitations of January 1997 shown in Figure 4 is a typical case for East 


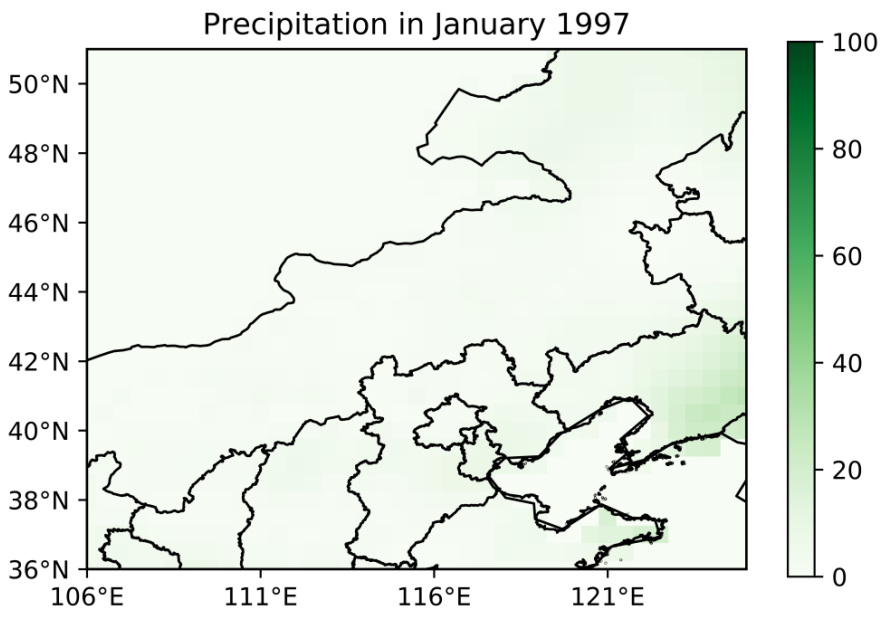

Figure 4. Monthly total precipitation in January 1997 in the Region. The green color illustrates the precipitation amount. The color bar to the right is the precipitation amount with $\mathrm{mm}$ as unit.

border precipitation because its maximum monthly total precipitation locates at the east border of the Region. More precisely the precipitation is in Liaoning province, the south part of Changbai Mountain. The maximum precipitation value is around $20 \mathrm{~mm}$.

In Figure 5, the precipitations of January 2002 stand for Northeast precipitation since its highest monthly total precipitation is in the northeast corner of the Region. It locates within $47^{\circ} \mathrm{N}-51^{\circ} \mathrm{N}, 116^{\circ} \mathrm{E}-125^{\circ} \mathrm{E}$. This area is within Inner Mongolia, in the north part of Daxinganling Mountain. The precipitation amount ranges from $20 \mathrm{~mm}$ to $40 \mathrm{~mm}$.

Figure 6 shows the precipitations of January 2008 which illustrates Southwest precipitation. The precipitation covers the area of $36^{\circ} \mathrm{N}-40^{\circ} \mathrm{N}, 106^{\circ} \mathrm{E}-112^{\circ} \mathrm{E}$, which is mainly in the north part of the farming-pastoral ecotone without reaching up to Hebei, Beijing or Tianjin. This is in the Liupanshan Mountain.

The precipitations in January 2017 in Figure 7 illustrate Coastal precipitation because the maximum precipitation location is within the east part of Shandong province with $36^{\circ} \mathrm{N}-38^{\circ} \mathrm{N}, 118^{\circ} \mathrm{E}-123^{\circ} \mathrm{E}$. This is the only part that thrusts into the ocean, with topography of plain.

The precipitations in Figure 8 stand for Inland precipitations, and they occurred in January 2018. Those precipitations are typical because they cover a band area from $112^{\circ} \mathrm{E} 36^{\circ} \mathrm{N}$ to $122^{\circ} \mathrm{E} 51^{\circ} \mathrm{N}$ with a linear line shape. The dark green color in the figure shows that the precipitation amount is largely saturated by the limit of $100 \mathrm{~mm}$ as shown on the color bar to the right of the figure. The use of this limit aims at firstly highlight the significance of the precipitation amount in January 2018, secondly be consistent with the scale of other figures. Those precipitations mainly locate in Shanxi, Northwest of Hebei and Northeast of Inner Mongolia provinces. The topography there are mountainous, including from south to north Taihangshan Mountain, west part of Yinshan Mountain and the whole length of Daxinganling Mountain. 


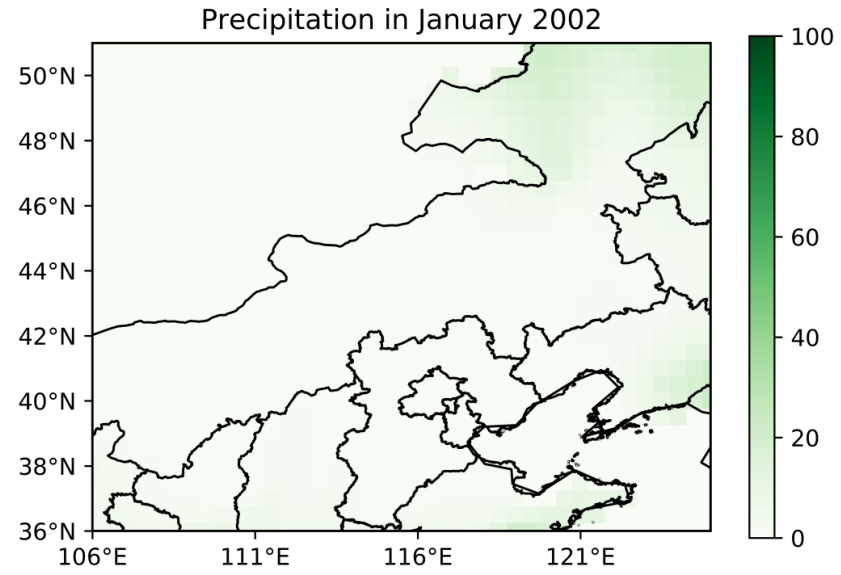

Figure 5. Monthly total precipitation in January 2002 in the Region. The green color illustrates the precipitation amount. The color bar to the right is the precipitation amount with $\mathrm{mm}$ as unit.

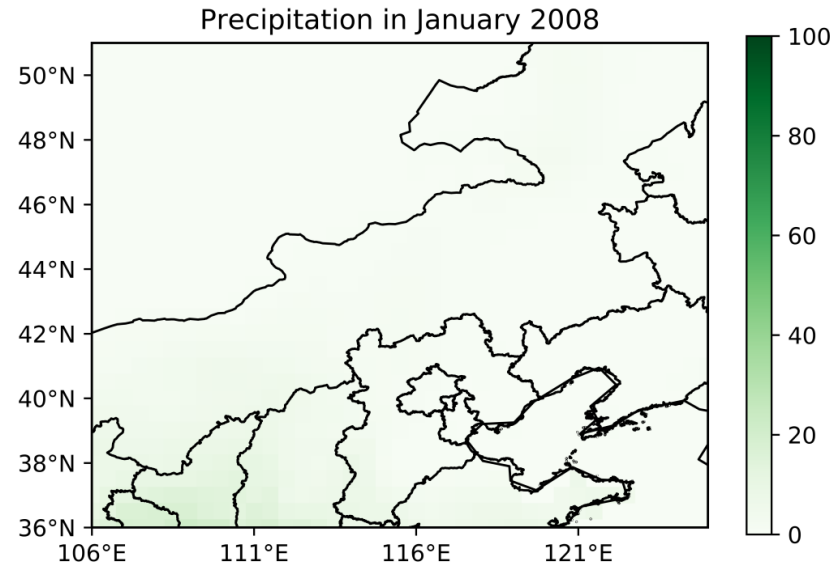

Figure 6. Monthly total precipitation in January 2008 in the Region. The green color illustrates the precipitation amount. The color bar to the right is the precipitation amount with $\mathrm{mm}$ as unit.

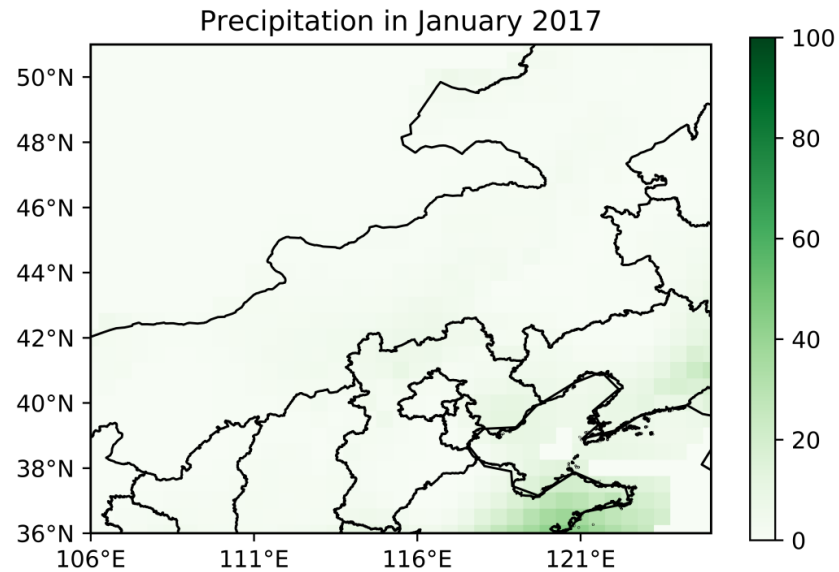

Figure 7. Monthly total precipitation in January 2017 in the Region. The green color illustrates the precipitation amount. The color bar to the right is the precipitation amount with $\mathrm{mm}$ as unit. 


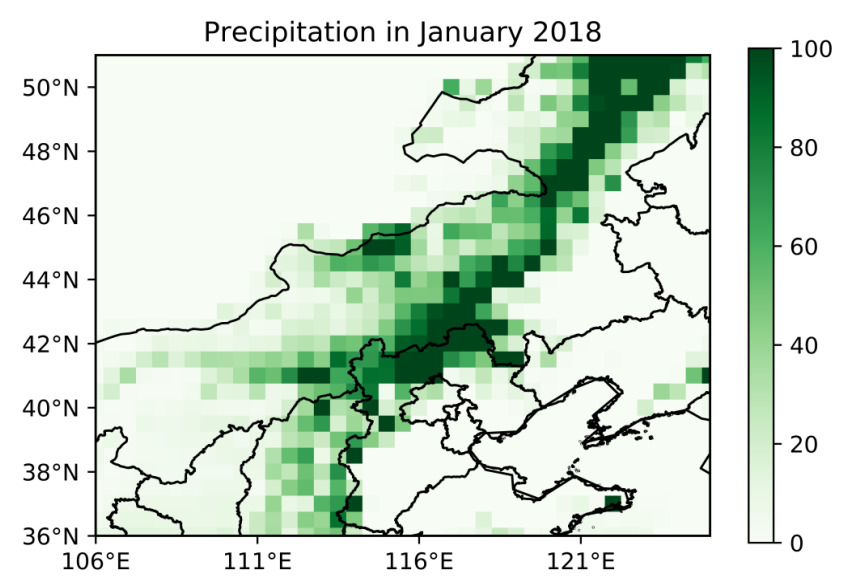

Figure 8. Monthly total precipitation in January 2018 in the Region. The green color illustrates the precipitation amount. The color bar to the right is the precipitation amount with $\mathrm{mm}$ as unit.

\subsection{Precipitation Rate}

Since we find that from 1988 to 2018 the winter precipitations are stable, we focus only on precipitations in Januaries from 2012 to 2018 . We need to know individual heavy precipitation event in the month to get more details about the phenomena, thus precipitation per hour is drawn for Januaries from 2012 to 2018 in Figure 9 as (a) to (g). The precipitations which have rates exceeding 2 $\mathrm{mm} / \mathrm{h}$ are chosen as "heavy" precipitations of the Region, because this rate value can clearly separate individual precipitation event within one month, in order to extract relative heavy precipitations. It should be noted that for one precipitation event, the time interval of non-precipitating should be less than 24 hours. There are 5 heavy precipitation events for 2012; 3 events for 2013; 7 events for 2014; 6 events for 2015; 8 events for 2016; 5 events for 2017 and 7 events for 2018. Among those precipitations, in January 2013 and 2017 precipitations have extreme values.

Figure 10 illustrates the sum of the heavy precipitation duration for each January from 2012 to 2018. The January 2018 has the longest duration, which corresponds to 260 hours. The January 2013 has the minimum duration, which is 90 hours. The growth of the heavy precipitation hours is obvious from 2013 to 2018. However, the months with the peak precipitations such as January 2013 and January 2017 do not have the largest precipitation duration hours. Thus, for January 2018 it is the precipitation frequency which drastically increased comparing to other months, which makes it the longest precipitation month.

\section{Precipitation Analyses of the Region}

The heavy precipitation events in January 2018 of the Region are analyzed in details, concluding the precipitation locations and the atmospheric circulations.

\subsection{Precipitation Locations}

According to the locations of the precipitations, there are five types of events: 


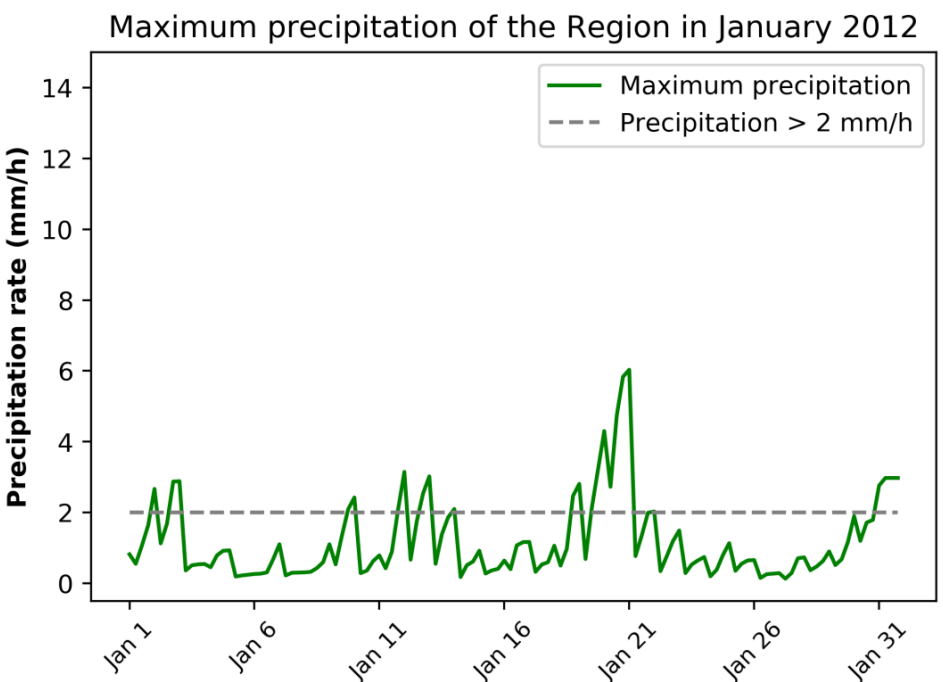

(a)

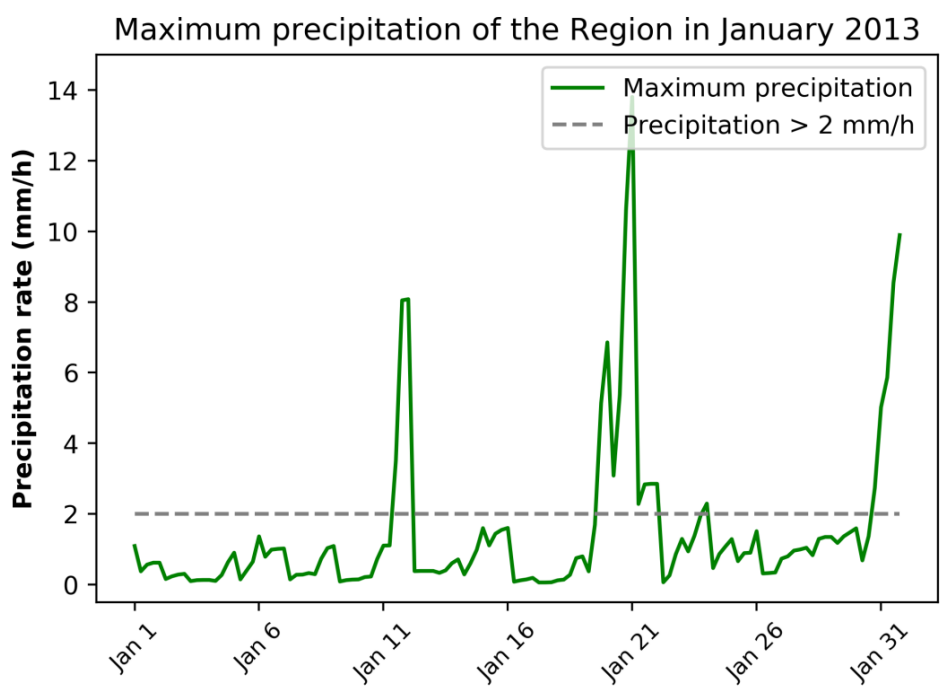

(b)

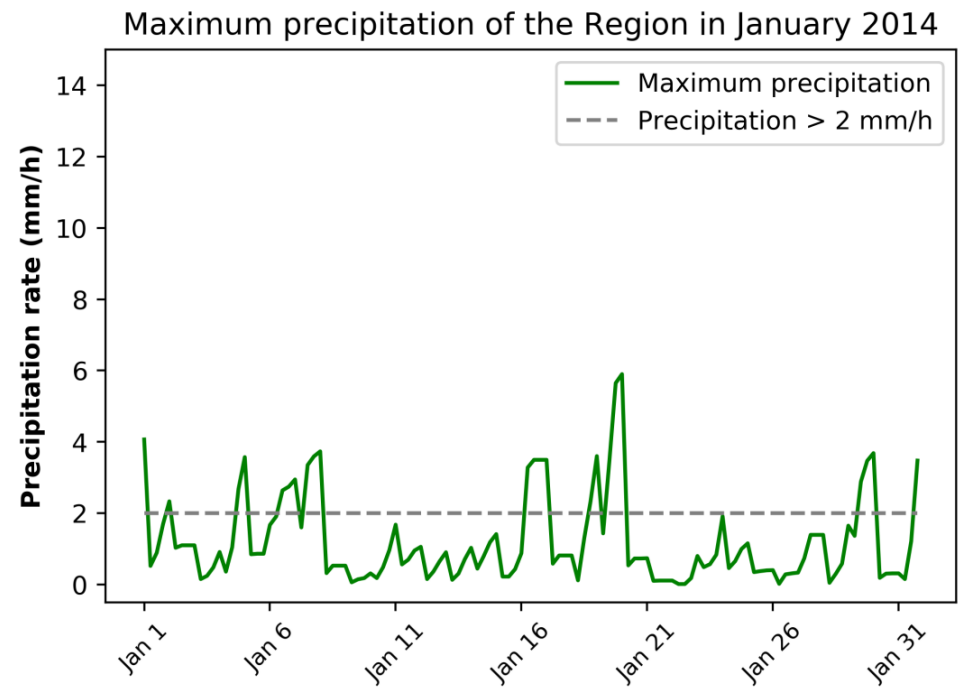

(c) 


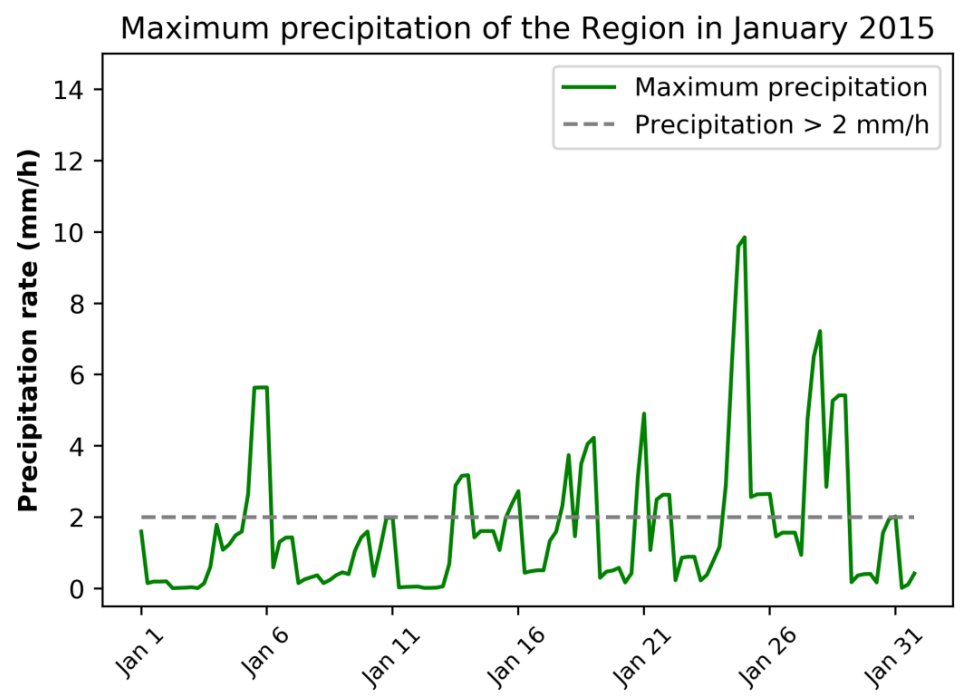

(d)

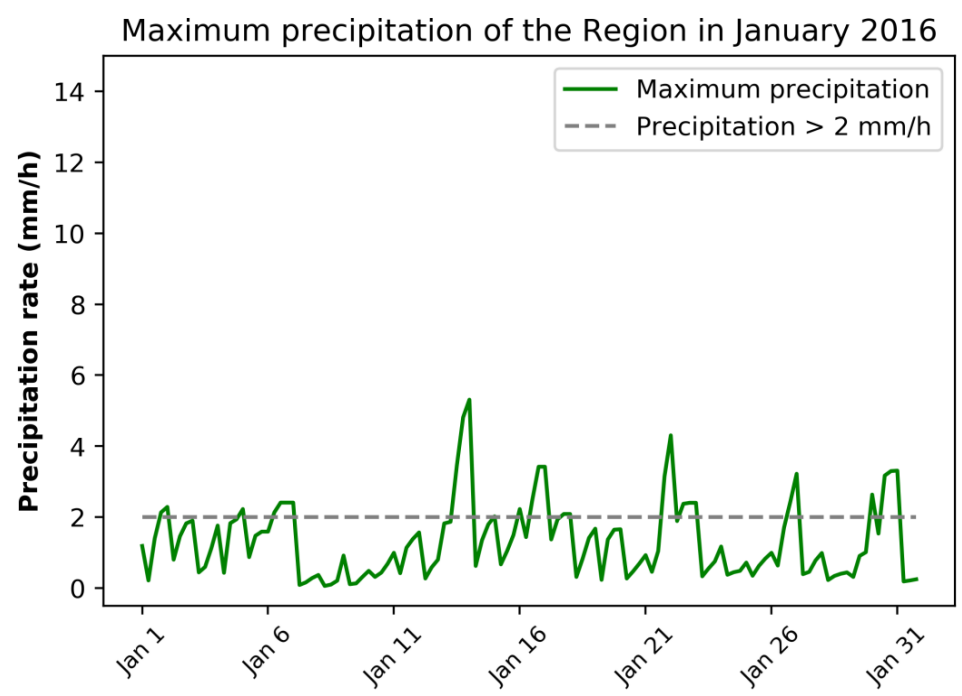

(e)

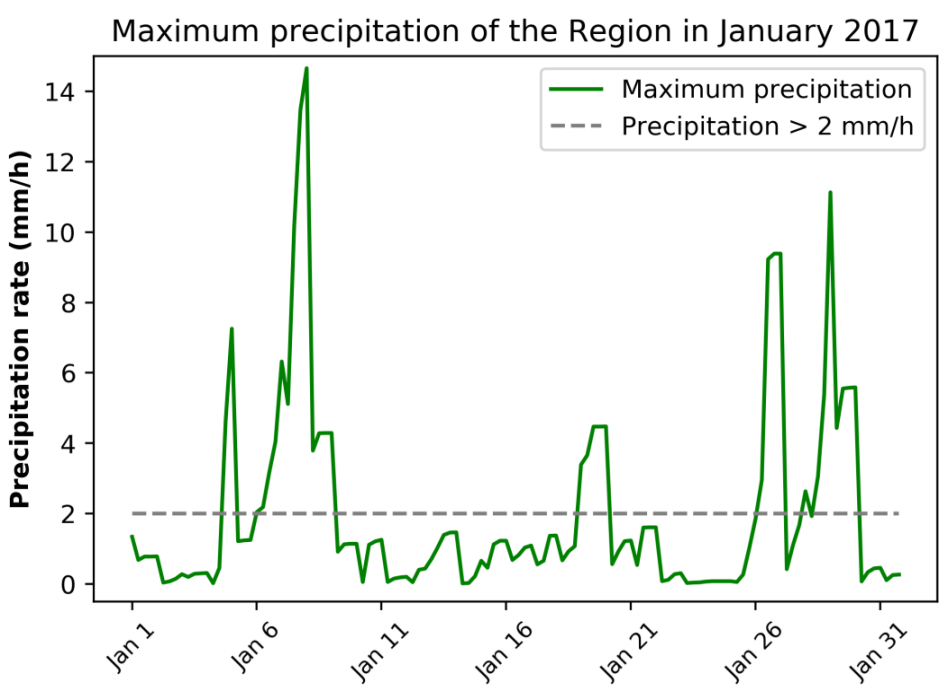

(f) 


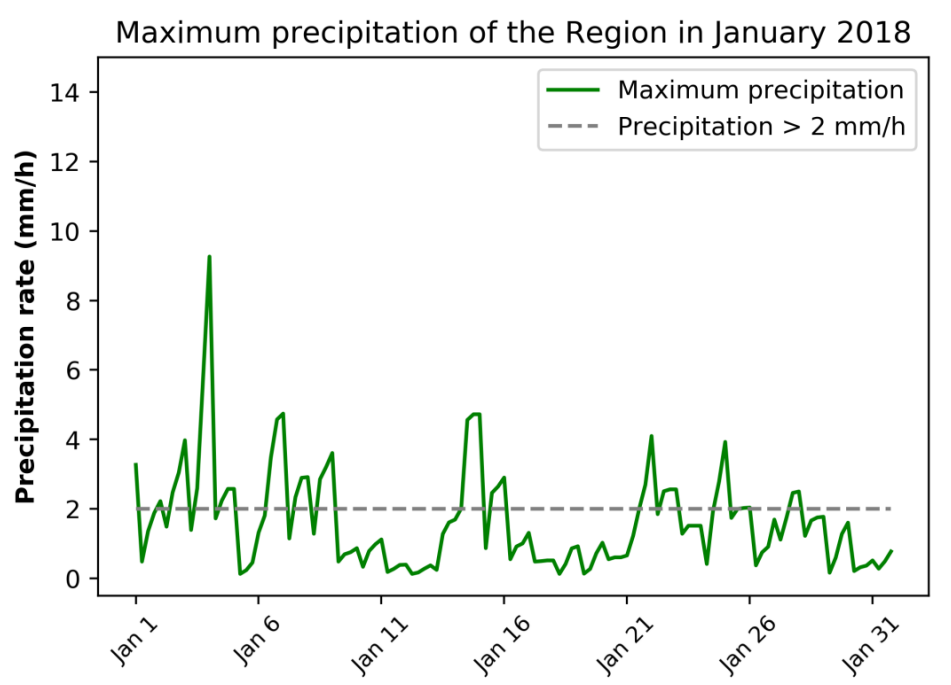

(g)

Figure 9. Hourly precipitation rates of the Region for Januaries from 2012 to 2018 (a) (g). The horizontal axis is the time line from the first day to the last day, and the vertical axis is the precipitation rate with $\mathrm{mm} / \mathrm{h}$ as unit. The fold line in dark green is the maximum precipitation rate within the Region, and the dashed gray line is the threshold of precipitation rate that equals to $2 \mathrm{~mm} / \mathrm{h}$.

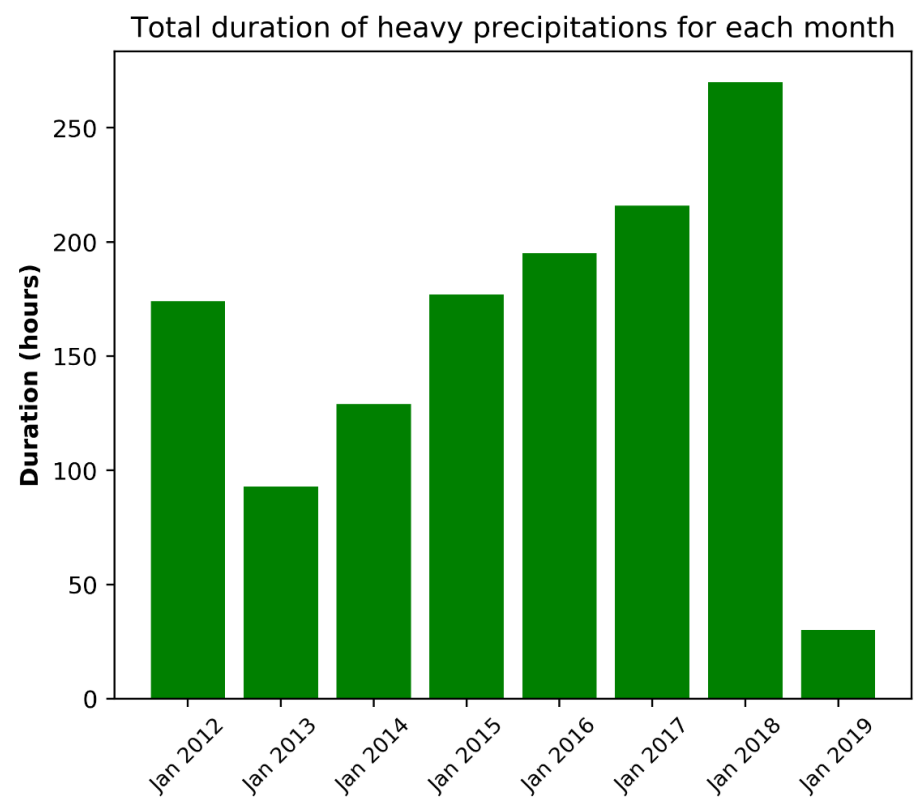

Figure 10. The sum of heavy precipitation durations in January from 2012 to 2018. The horizontal axis is time line, and the vertical axis is the total duration with hours as unit. The dark green bars depict the duration.

Northeast precipitation, Southwest precipitation, West to east precipitation, East border precipitation and Inland precipitation. For the precipitations with the same names as previously illustrated examples, the precipitation locations within the Region are the same. The five types of precipitations are shown in Figure 11. 


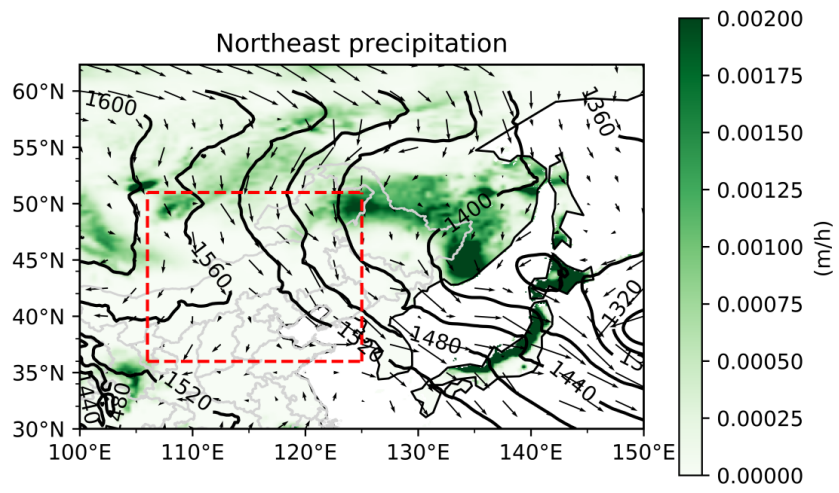

(a)

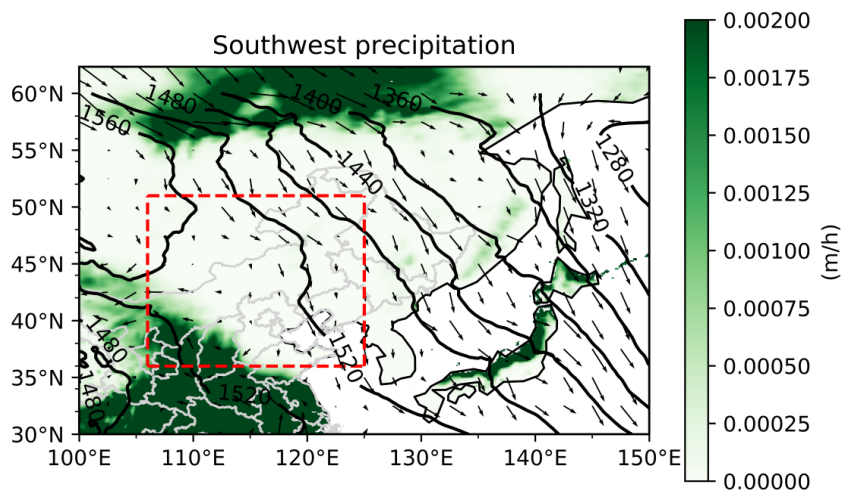

(b)

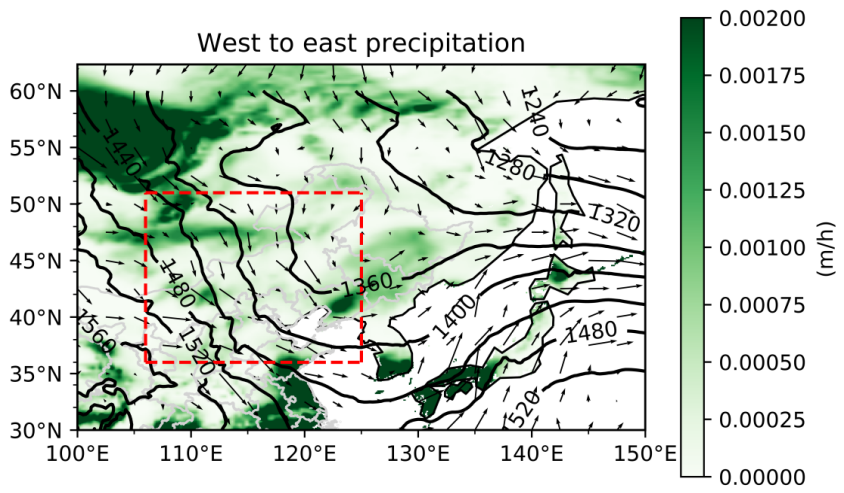

(c)

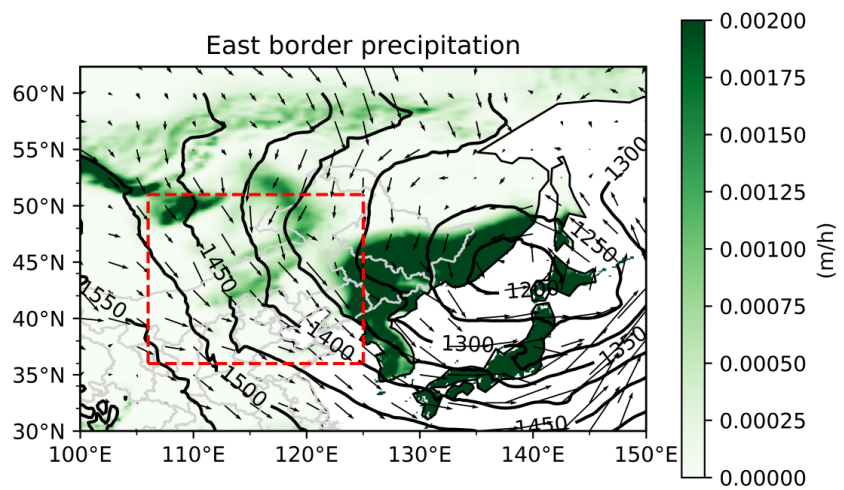

(d) 


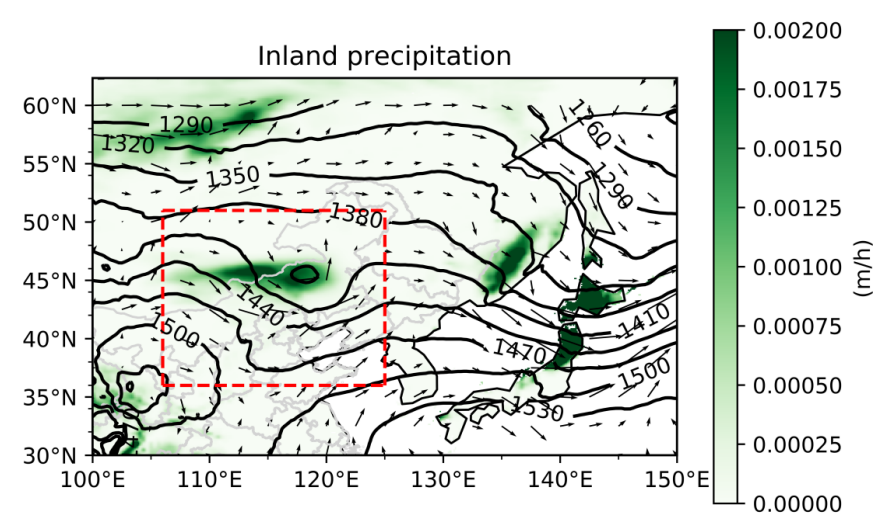

(e)

Figure 11. Precipitations with wind field (arrows), geopotential heights (curved lines with numbers on them) and precipitations (dark green patches). The color bar to the right of the figure shows the precipitation rate with $\mathrm{m} / \mathrm{s}$ as unit. The area is extended for $100^{\circ} \mathrm{E}-$ $150^{\circ} \mathrm{E}, 30^{\circ} \mathrm{N}-62^{\circ} \mathrm{N}$. The red dashed rectangle limits the Region. There are five types of precipitations named after their locations, and they are (a) Northeast precipitation; (b) Southwest precipitation; (c) West to east precipitation; (d) East border precipitation and (e) Inland precipitation.

For the Northeast precipitation, the highest precipitation is in the northeast corner of the Region. The wind steps down from the north, and a trough is to the southeast of Japan, on the Pacific. The Southwest precipitation has relative high geopotential height comparing to the northeast corner in the Region. The West to east precipitation has many precipitation spots dispersing over the whole Region. The geopotential height is also higher in the southwest corner and lower in the northeast corner of the Region. For the East border precipitation, the precipitations in the Region are centralized at the east border to the Region. A low pressure trough is above the Sea of Japan. Finally, the Inland precipitation has a trough with its center at $118^{\circ} \mathrm{E} 46^{\circ} \mathrm{N}$. The geopotential height is high to the south and low to the north.

\subsection{Atmospheric Circulation Patterns}

The atmospheric circulation for the Northeast precipitation is shown in Figure 12.

At $200 \mathrm{hPa}$ the Region is dominated by west wind. At $500 \mathrm{hPa}$ two cyclones are created, the first one is at $88^{\circ} \mathrm{E} 48^{\circ} \mathrm{N}$, and the second is at $131^{\circ} \mathrm{E} 45^{\circ} \mathrm{N}$. The northeast corner of the Region is mainly dominated by north wind induced by the second cyclone. Despite at $700 \mathrm{hPa}$ the two cyclones are subdued, the northeast corner of the Region is still influenced by the north wind. At $850 \mathrm{hPa}$ the first cyclone loses its pattern, while the second cyclone persists. Through the whole precipitation event, at 500 and $700 \mathrm{hPa}$ a cyclone centered at $122^{\circ} \mathrm{E} 48^{\circ} \mathrm{N}$ is moving towards the second cyclone, and merges with it. At $850 \mathrm{hPa}$ this moving cyclone does not appear. The second cyclone occludes throughout the precipitation event above the Sea of Japan. The Northeast precipitation of the Region is caused by the occluding cyclone above the Sea of Japan.

The Southwest precipitation is shown in Figure 13. 


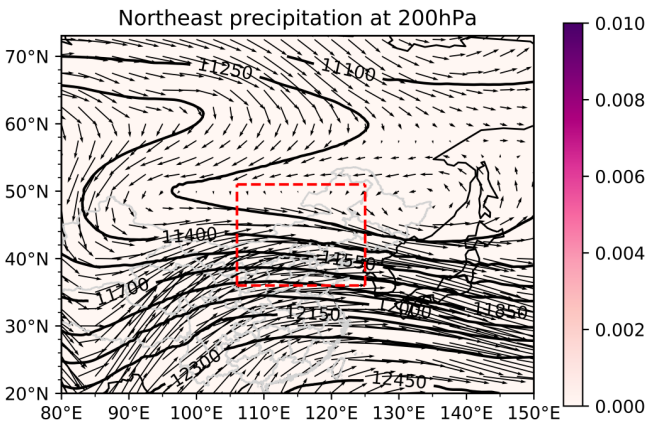

(a)

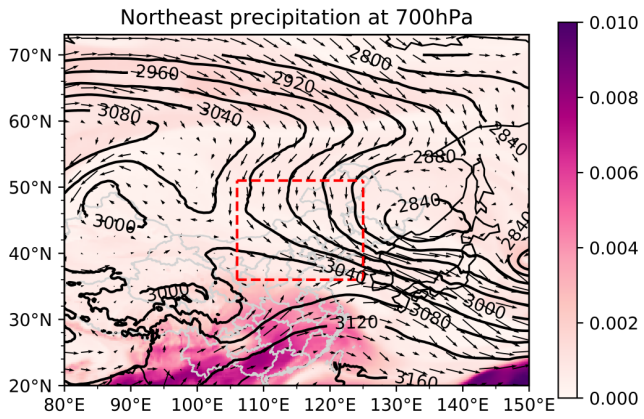

(c)

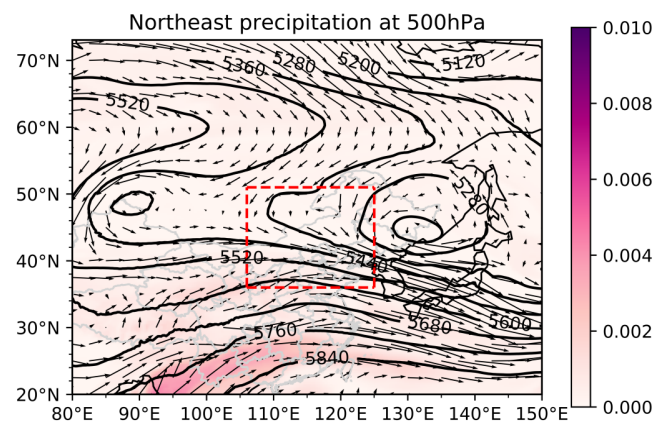

(b)

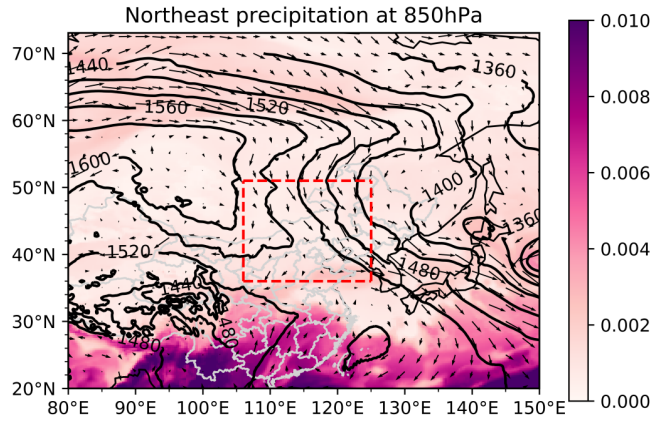

(d)

Figure 12. The Northeast precipitation with wind field (arrows), relative humidity (purple patches) and geopotential height at (a) $200 \mathrm{hPa},(\mathrm{b}) 500 \mathrm{hPa},(\mathrm{c}) 700 \mathrm{hPa}$ and (d) $850 \mathrm{hPa}$. The observation area spans $80^{\circ} \mathrm{E}-150^{\circ} \mathrm{E}, 20^{\circ} \mathrm{N}-73^{\circ} \mathrm{N}$. The color bar to the right illustrates relative humidity. The red dashed rectangle limits the area of the Region.

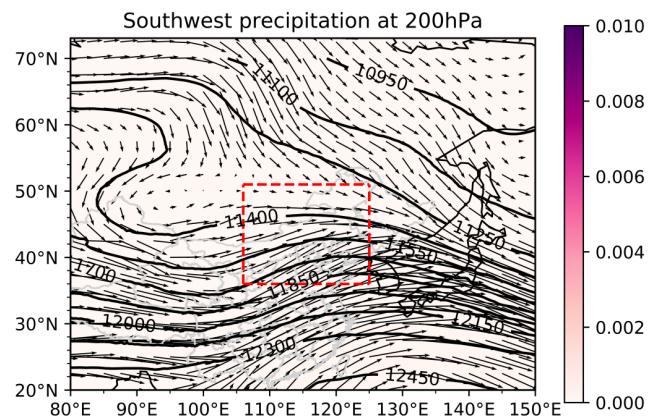

(a)

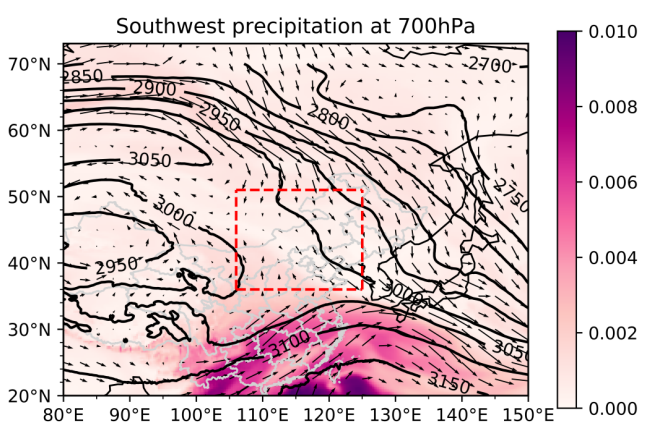

(c)

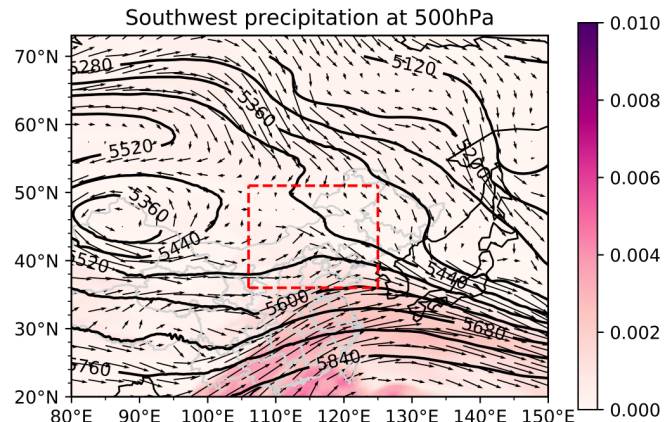

(b)

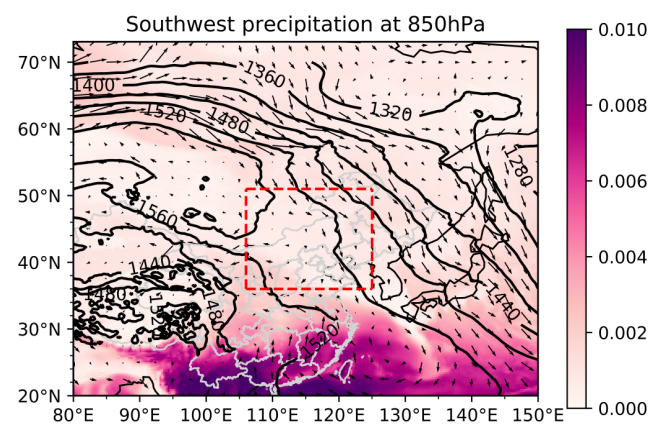

(d)

Figure 13. The Southwest precipitation with wind field (arrows), relative humidity (purple patches) and geopotential height at (a) $200 \mathrm{hPa}$, (b) $500 \mathrm{hPa}$, (c) $700 \mathrm{hPa}$ and (d) $850 \mathrm{hPa}$. The observation area spans $80^{\circ} \mathrm{E}-150^{\circ} \mathrm{E}, 20^{\circ} \mathrm{N}-73^{\circ} \mathrm{N}$. The color bar to the right illustrates relative humidity. The red dashed rectangle limits the area of the Region. 
At $200 \mathrm{hPa}$ the west wind dominates in the Region. At $500 \mathrm{hPa}$ a cyclone at $85^{\circ} \mathrm{E} 46^{\circ} \mathrm{N}$ appears, and its flow pattern influences the wind field in the Region. At $20^{\circ} \mathrm{N}, 90^{\circ} \mathrm{E}-110^{\circ} \mathrm{E}$ strong southwest wind with moisture intrudes into the Region. Combining the influence induced by the cyclone, the southwest and the northwest wind interact inside the Region. At $700 \mathrm{hPa}$, the cyclone is subdued and the influence inside the Region disappears. A strong south wind with relative high moisture blows into the southwest corner of the Region, confronting the north dry wind. At $850 \mathrm{hPa}$, the south wind is pushed southward by the north dry wind, only remaining in the southwest corner of the Region. Throughout the precipitation event, no significant persisting cyclones are present. Instead, the remarkable invasion of the south wind with high moisture into the southwest corner of the Region which dominated by north dry wind, causes the Southwest precipitation.

Figure 14 illustrates the West to east precipitation.

At $200 \mathrm{hPa}$, the Region is dominated by west wind. At $500 \mathrm{hPa}$ a convergence appears at $110^{\circ} \mathrm{E} 44^{\circ} \mathrm{N}$ in the central part of the Region. Stepping downward to 700 and $850 \mathrm{hPa}$, the convergence is gradually weakening until losing its patterns. This convergence is in forms of a cyclone at 500 and $700 \mathrm{hPa}$ at the beginning hours of the precipitation. As it moves eastward, it losses cyclone patterns

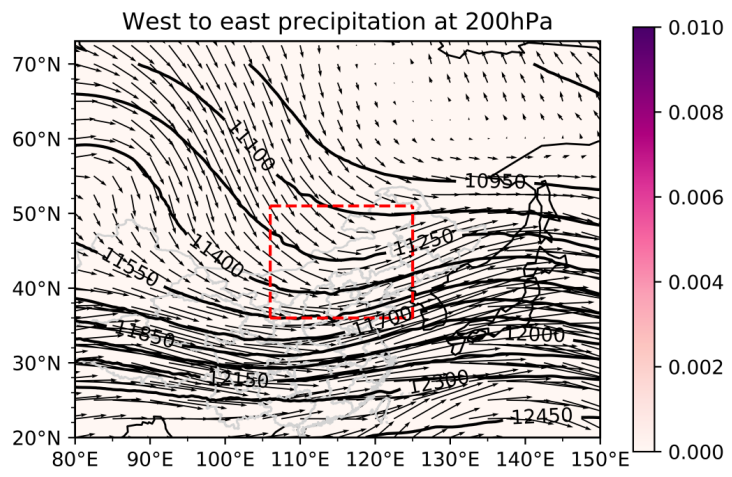

(a)

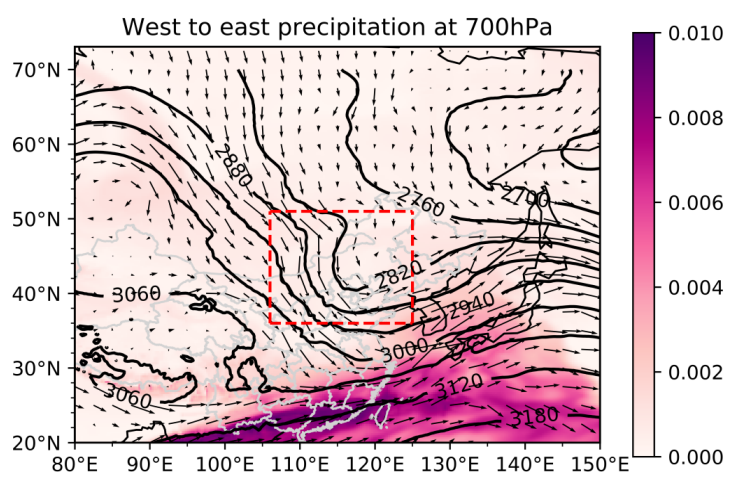

(c)

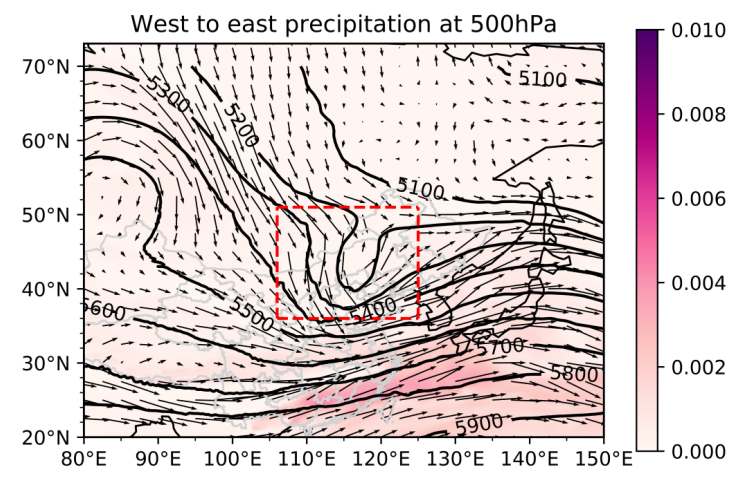

(b)

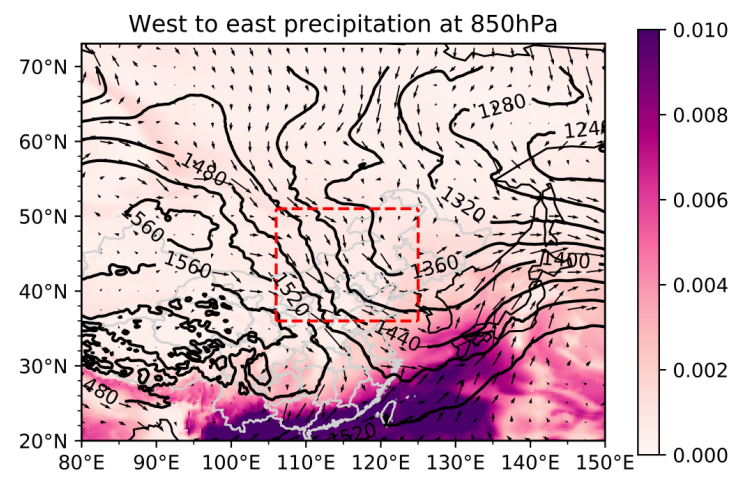

(d)

Figure 14. The West to east precipitation with wind field (arrows), relative humidity (purple patches) and geopotential height at (a) $200 \mathrm{hPa}$, (b) $500 \mathrm{hPa}$, (c) $700 \mathrm{hPa}$ and (d) $850 \mathrm{hPa}$. The observation area spans $80^{\circ} \mathrm{E}-150^{\circ} \mathrm{E}, 20^{\circ} \mathrm{N}-73^{\circ} \mathrm{N}$. The color bar to the right illustrates relative humidity. The red dashed rectangle limits the area of the Region. 
progressively. This time evolution process is not presented here because of its huge size in figures. At $850 \mathrm{hPa}$, no significant cyclone features are observed. This West to east precipitation is due to convergence caused by pressure pattern in the atmosphere.

The East border precipitations are represented in Figure 15.

At $200 \mathrm{hPa}$, northwest wind is prominent in the Region. At 500 and $700 \mathrm{hPa}$, north wind dominates, and a cyclone without clear patterns is formed at $133^{\circ} \mathrm{E}$ $45^{\circ} \mathrm{N}$, near the Sea of Japan. At $850 \mathrm{hPa}$, that cyclone enforced its patterns, and it locates just above the Sea of Japan. During the precipitations, the cyclone above the Sea of Japan only appears at ground level. Consequently, the East border precipitation is caused by the cyclone above the Sea of Japan.

The Inland precipitation is shown in Figure 16.

From 200 to $700 \mathrm{hPa}$ the west wind dominates in the Region. A slight curvature of the geopotential line appears at $500 \mathrm{hPa}$ at $115^{\circ} \mathrm{E} 46^{\circ} \mathrm{N}$ and enhances downward until $850 \mathrm{hPa}$ to form a small cyclone. During the precipitation, at 200 and $500 \mathrm{hPa}$ the Region is dominated by west wind. At $700 \mathrm{hPa}$, strong southwest wind invades the Region, interacting with west wind. This interaction leads to a small convergence in the wind field. At $850 \mathrm{hPa}$, a small inland cyclone is formed due to the active interactions of the two winds. That is, the Inland precipitation is caused by a ground breeze induced small cyclone.

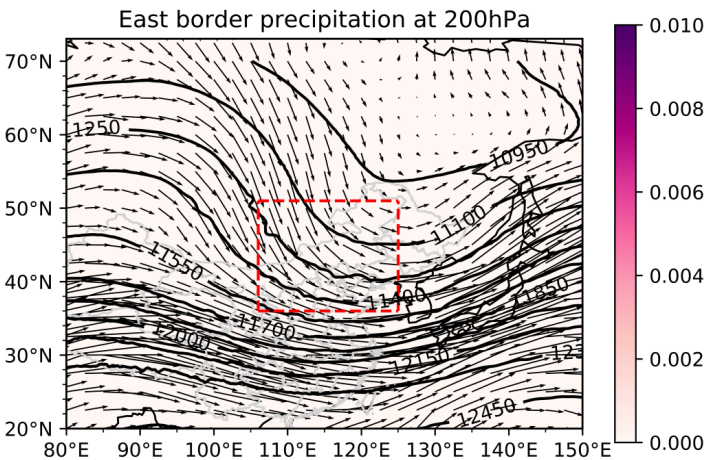

(a)

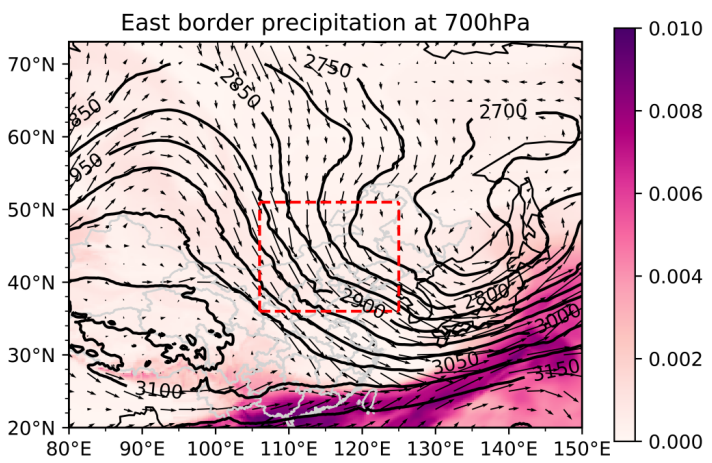

(c)

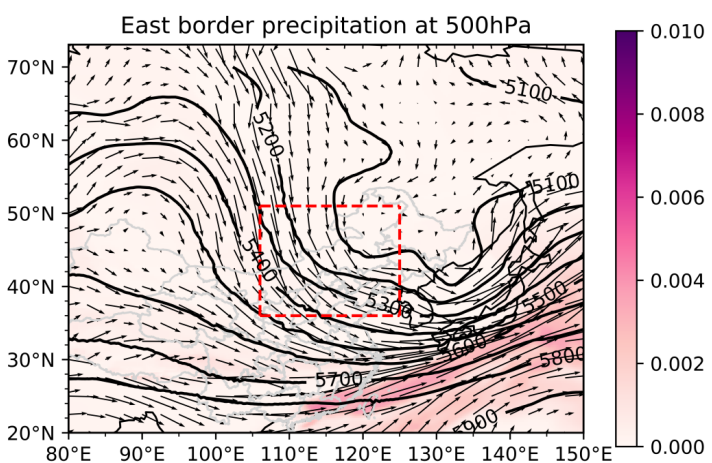

(b)

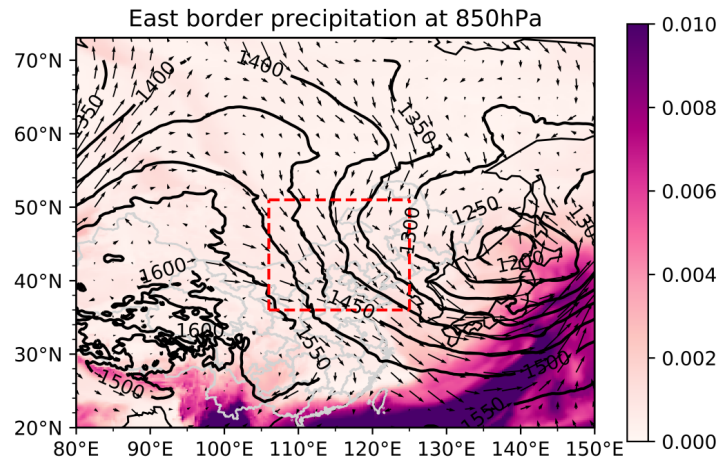

(d)

Figure 15. The East border precipitation with wind field (arrows), relative humidity (purple patches) and geopotential height at (a) $200 \mathrm{hPa}$, (b) $500 \mathrm{hPa}$, (c) $700 \mathrm{hPa}$ and (d) $850 \mathrm{hPa}$. The observation area spans $80^{\circ} \mathrm{E}-150^{\circ} \mathrm{E}, 20^{\circ} \mathrm{N}-73^{\circ} \mathrm{N}$. The color bar to the right illustrates relative humidity. The red dashed rectangle limits the area of the Region. 


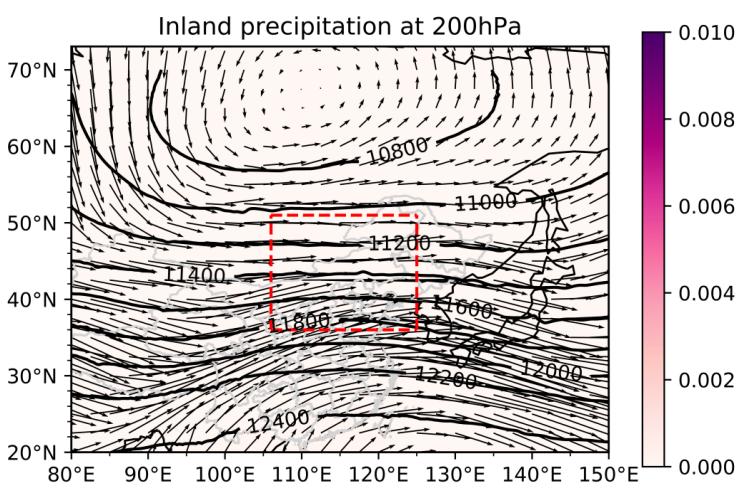

(a)

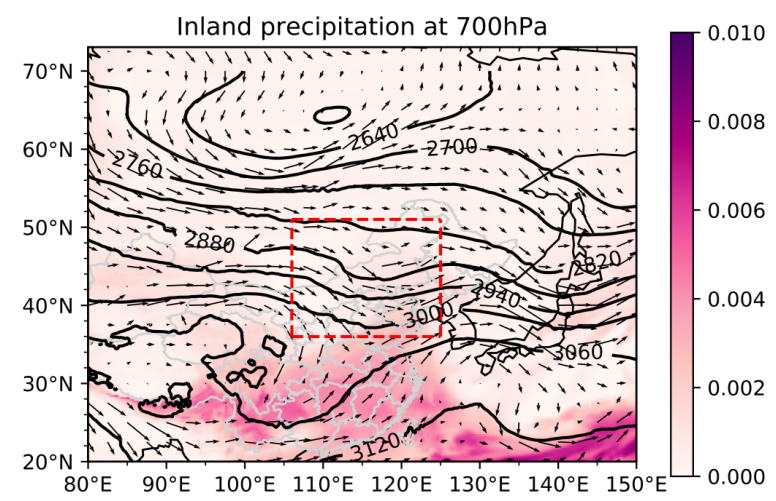

(c)

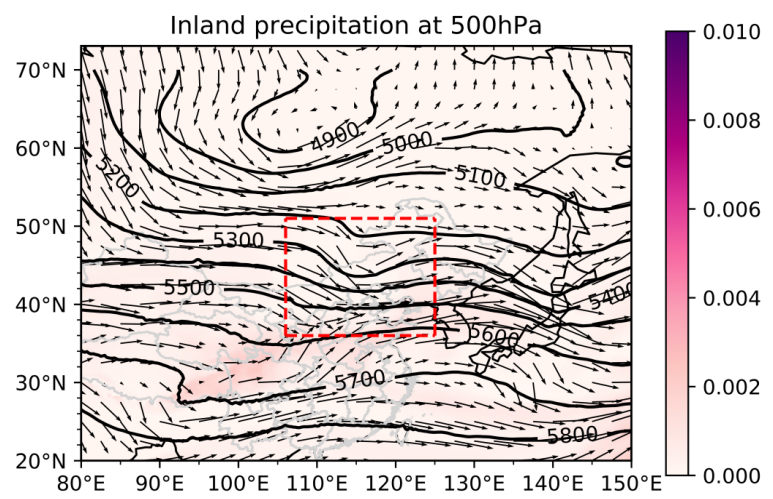

(b)

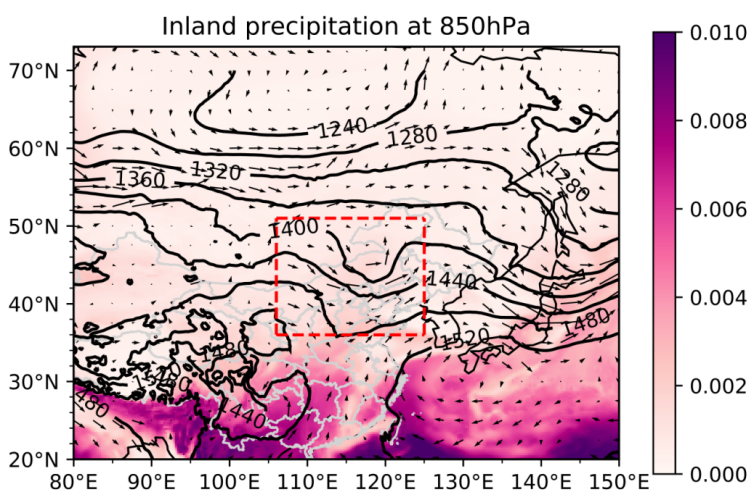

(d)

Figure 16. The Inland precipitation with wind field (arrows), relative humidity (purple patches) and geopotential height at (a) 200 $\mathrm{hPa}$, (b) $500 \mathrm{hPa}$, (c) $700 \mathrm{hPa}$ and (d) $850 \mathrm{hPa}$. The observation area spans $80^{\circ} \mathrm{E}-150^{\circ} \mathrm{E}, 20^{\circ} \mathrm{N}-73^{\circ} \mathrm{N}$. The color bar to the right illustrates relative humidity. The red dashed rectangle limits the area of the Region.

\section{Discussion}

The five precipitation types in January 2018 are Northeast precipitation, Southwest precipitation, West to East precipitation, East border precipitation and Inland precipitation. Among the precipitations, the Northeast precipitation is caused by occluding cyclones above the Sea of Japan, while the East border precipitation is induced by the same cyclone but formed at sea level. The Southwest precipitation is wrought by the frontal effects between southwest moist wind and the northwest dry wind. The West to east precipitation is due to the change of pressure pattern inside the Region, and the Inland precipitation is induced by ground breezes.

Comparing to other typical precipitations through the 30 winters, the Coastal precipitation in January 2017 is not seen, while the West to east precipitation and Inland precipitation are additional types in January 2018. The former can also be contributed to existence of cyclones above the ocean surface because of its location, and the latter is mainly due to the pressure change and local breezes of the Region. The high amount of monthly total precipitation in January 2018 resulted from a relatively high precipitation frequency, rather than an augmentation of precipitation intensities. Thus, the high precipitation amount in Janu- 
ary 2018 is caused by active atmospheric circulation above the Region.

\section{Conclusions}

For the Region in January 2018, the maximum of the monthly total precipitation is 4 times more than that in other winter months for the recent 30 years. The highest value of precipitation mainly concentrates along the mountainous areas. For these precipitations, there are five major types of precipitations named after their locations: Northeast precipitation, Southwest precipitation, West to east precipitation, East border precipitation and Inland precipitation. It is found that a continuous moderate precipitation phenomenon is dominant in the Region in January 2018, instead of increase in either precipitation intensities or number of intense precipitations. Such precipitations are mainly caused by cyclones in the vicinity of the studied Region. The Northeast precipitation and the East border precipitation are both induced by cyclones above the Sea of Japan, but the former is caused by an occluding cyclone while the latter by a small cyclone formed at sea level. The Southwest precipitation is frontal precipitation between southwest moist wind and northwest dry wind. The West to east precipitation is generated by the change of atmospheric pressure above the Region, and the Inland precipitation is risen by ground breezes.

For future work, the causes of such cyclone frequent weather in the Region should be exploited from a global perspective. More work should be investigated in the relationship between the cyclone occurrence frequency in the Region and the Indian Ocean Dipole, the El Nino Southern Oscillation and the Pacific Decadal Oscillation.

\section{Acknowledgements}

All data used are publicly available, and no funding is received for this research.

\section{Conflicts of Interest}

The author declares no conflicts of interest regarding the publication of this paper.

\section{References}

[1] Hui, J., Bai, Z. and Ye, B. (2021) Eco-Environment Evaluation of Grassland Based on Remote Sensing Ecological Index: A Case in Hulunbuir Area, China. Journal of Computer and Communications, 9, 203-213. https://doi.org/10.4236/jcc.2021.96012

[2] Li, M. and Guo, X. (2014) Long Term Effect of Major Disturbances on the Northern Mixed Grassland Ecosystem-A Review. Open Journal of Ecology, 4, 214-233. https://doi.org/10.4236/oje.2014.44021

[3] Zhang, C., Zhang, Y. and Li, J. (2019) Grassland Productivity Response to Climate Change in the Hulunbuir Steppes of China. Sustainability, 11, 6760.

https://doi.org/10.3390/su11236760

[4] Zainelabdeen, Y., Yan, R., Xin, X., Yan, Y., Ahmed, A., Hou, L. and Zhang, Y. (2020) The Impact of Grazing on the Grass Composition in Temperate Grassland. 
Agronomy, 10, 19. https://doi.org/10.3390/agronomy10091230

[5] Liu, M., Liu, G., Gong, L., Wang, D. and Sun, J. (2014) Relationships of Biomass with Environmental Factors in the Grassland Area of Hulunbuir, China. PLoS ONE, 9, e102344. https://doi.org/10.1371/journal.pone.0102344

[6] Sawada, M., Anzai, R. and Ueno, K. (2019) Continuous Heavy Precipitation with a Winter Occluding Cyclone Captured by GPM Satellite in Central Japan.

[7] Kawase, H., Sasai, T., Yamazaki, T., Ito, R., Dairaku, K., Suginoto, S., Sasaki, H., Murata, A. and Nosaka, M. (2018) Characteristics of Synoptic Conditions for Heavy Snowfall in Western to Northeastern Japan Analyzed by the 5-km Regional Climate Ensemble Experiments. Journal of the Meteorological Society of Japan. Ser. II, 96, 161-178. https://doi.org/10.2151/jmsj.2018-022

[8] Ueno, K. and Ando, N. (2015) Occurrence Tendency of Heavy Rainfall or Snowfall in the Inland District of Japan in Winter. Japanese Society of Snow and Ice, 77, 397-410. https://www.seppyo.org/publication/seppyo/

[9] Eito, H., Kato, T., Yoshizaki, M. and Adachi, A. (2005) Numerical Simulation of the Quasi-Stationary Snow Band Observed over the Southern Coastal Area of the Sea of Japan on 16 January 2001. Journal of the Meteorological Society of Japan. Ser. II, 83, 551-576. https://doi.org/10.2151/jmsj.83.551

[10] Sawada, M. and Ueno, K. (2021) Heavy Winter Precipitation Events with Extratropical Cyclone Diagnosed by GPM Products and Trajectory Analysis. Journal of the Meteorological Society of Japan. Ser. II, 99, 473-496.

[11] Chartrand, J. and Pausata, F.S.R. (2020) Impacts of the North Atlantic Oscillation on Winter Precipitations and Storm Track Variability in Southeast Canada and the Northeast United States. Weather and Climate Dynamics, 1, 731-744. https://doi.org/10.5194/wcd-1-731-2020

[12] Stone, D.A., Weaver, A.J. and Zwiers, F.W. (2000) Trends in Canadian Precipitation Intensity. Atmosphere-Ocean, 38, 321-347. https://doi.org/10.1080/07055900.2000.9649651

[13] Bonsal, B. and Shabbar, A. (2008) Impacts of Large-Scale Circulation Variability on Low Streamflows over Canada: A Review. Canadian Water Resources Journal, 33, 137-154. https://doi.org/10.4296/cwrj3302137

[14] Whan, K. and Zwiers, F. (2017) The Impact of ENSO and the NAO on Extreme Winter Precipitation in North America in Observations and Regional Climate Models. Climate Dynamics, 48, 1401-1411. https://doi.org/10.1007/s00382-016-3148-X

[15] Liu, X., Ma, X., Chang, P., Jia, Y., Fu, D., Xu, G., Wu, L., Saravanan, R. and Patricola, C. (2021) Ocean Fronts and Eddies Force Atmospheric Rivers and Heavy Precipitation in Western North America. Nature Communications, 12, 1-10. https://doi.org/10.1038/s41467-021-21504-w

[16] Alexander, M., Scott, J., Swales, D., Hughes, M., Mahoney, K. and Smith, C. (2015) Moisture Pathways into the U.S. Intermountain West Associated with Heavy Winter Precipitation Events. Journal of Hydrometeorology, 16, 1184-1206. https://doi.org/10.1175/JHM-D-14-0139.1

[17] Azirani, T.A., Azizi, G., Asadi, A. and Davoudi, M. (2016) The Role of Blocking System in Heavy Precipitation of Iran (a Case Study: Southeast of Iran January 2008). Arabian Journal of Geosciences, 9, 1-15. https://doi.org/10.1007/s12517-016-2588-2

[18] Harnack, R.P., Jensen, D.T. and Cermak III, J.R. (1998) Investigation of Upper-Air Conditions Occurring with Heavy Summer Rain in Utah. International Journal of Climatology, 18, 701-723. 
https://doi.org/10.1002/(SICI)1097-0088(19980615)18:7<701::AID-JOC265>3.0.CO; 2-S

[19] Tomozeiu, R., Stefan, S. and Busuioc, A. (2005) Winter Precipitation Variability and Large-Scale Circulation Patterns in Romania. Theoretical and Applied Climatology, 81, 193-201. https://doi.org/10.1007/s00704-004-0082-3

[20] Kodama, C., Stevens, B., Mauritsen, T., Seiki, T. and Satoh, M. (2019) A New Perspective for Future Precipitation Change from Intense Extratropical Cyclones. Geophysical Research Letters, 46, 12435-12444. https://doi.org/10.1029/2019GL084001

[21] Guo, Z., Zobeck, T.M., Zhang, K. and Li, F. (2013) Estimating Potential Wind Erosion of Agricultural Lands in Northern China Using the Revised Wind Erosion Equation and Geographic Information Systems. Journal of Soil and Water Conservation, 68, 13-21. https://doi.org/10.2489/jswc.68.1.13 